\title{
供用後に変状が発生した 脆弱岩ずりを用いた盛土の物性変化と変状原因
}

\author{
澤野 幸輝 1 - 長尾 和之 2 -加村 晃良 3 ・風間 基樹 4 \\ 1正会員 株式会社ネクスコ・エンジニアリング東北（†980-0013 仙台市青葉区花京院2-1-65） \\ E-mail:k.sawano.sa@e-nexco.co.jp \\ 2正会員 東日本高速道路株式会社 東北支社（广980-0021 仙台市青葉区中央3-2-1） \\ E-mail: k.nagao.ab@e-nexco.co.jp \\ 3 正会員 東北大学助教 大学院工学研究科（广980-8579 仙台市青葉区荒巻字青葉6-6-06） \\ E-mail: akiyoshi.kamura.a4@tohoku.ac.jp \\ 4フェロー会員 東北大学教授 大学院工学研究科（†980-8579 仙台市青葉区荒巻字青葉6-6-06） \\ E-mail: motoki.kazama.b2@tohoku.ac.jp
}

\begin{abstract}
グリーンタフ地域では現地発生土の脆弱岩ずりを利用した盛土が数多く存在し, それらは空気間隙率が 15\%未満となるよう品質管理して構築されてきた。 しかし, 近年, 脆弱岩盛土の変状が増え, 高速道路の 維持管理の現場で問題となっている. 本報告は, 供用開始数年後から舗装面にクラックが断続的に発生し た盛土の調査結果から物性変化を整理し, 盛土の継時的な物性変化と変状との因果関係を考察した。 スレ ーキングする岩ずりは，供用後初期段階から細粒化が進行したと推察した。また，細粒分が雨水の浸透・ 流出過程で下方に移動し, 上方の法肩部でゆるみや空洞化が発生した. 盛土下方では細粒化し粘土化した 盛土材が地下水位を上昇させ, 盛土の不安定化を助長させたものと推察した。 また, 実際に調整した粒度 分布による透水性の変化も評価した.
\end{abstract}

Key Words : embankment, slaking, physical properties, particle movement, change in permeability

\section{1. はじめに}

高速道路建設は，その工事規模から地形改変が大きく 周辺環境一与える負荷が大きい。 また，経済性や環境面 への配慮から，切土やトンネル掘削での現地発生土を積 極的に盛土材などに利用することが多い.しかしながら， 泥岩や凝灰岩などの軟質な堆積岩類の中には, 乾湿作用 を繰返し受けると容易に細粒化するスレーキング現象が 発生するものがあることも広く知られている ${ }^{1)}$ ，そこで スレーキング性を有する脆弱岩を積極的に利用しようと する研究 ${ }^{244)}$ ，実際に盛土として施工する場合の管理手 法の策定 ケかが行われてきた。 なお，高速道路の建設段 階では，その細粒化に伴う盛土体の圧縮沈下や強度低下 が問題となるため，スレーキング率が約 $30 \%$ 以上となる スレーキング性材料を路体に使用寸る場合は，空気間隙 率が $15 \%$ 以下 ${ }^{8)}$ となるように締固めを行い，施工にあた っては材料をできるだけ小粒径として薄層で敷均し, タ ンピングローラーや大型振動ローラ等により破砕転圧を 行っている. この様に, 脆弱岩を用いて高速道路盛土を
構築する場合は，十分な締固めを行って建設してきてい るが，2009年 8 月 11 日に駿河湾沖で発生した地震では, 東名高速自動車道牧之原 SA 付近で盛土のり面の崩壊が 発生した. その素因として, 盛土材のスレーキングによ る強度低下，細粒化に伴う透水性の低下が指摘されてい る ${ }^{9}$. この様に，建設時に入念な締固めを行っていたと しても, 脆弱岩を用いた盛土は経年的な変化が生じる場 合があると言える.

脆弱岩を起源とした盛土材のスレーキングに伴うせん 断強度や粒径の変化を室内実験で確認している研究が多 くみられるが，実際に現地で変状が発生している盛土を 経時的に追跡したものはない，そこで，本論文は，供用 開始数年後から舗装面にクラックが断続的に発生した谷 埋め盛土の物理特性を調査した.

\section{2. スレーキング性を有する地盤材料の既往研究}

これまでスレーキング性を有する地盤材料について, 
スレーキング現象による幾つかの特徵に着目した研究が 多く行われてきた。 日下部ら ${ }^{10}$ は, 岩石の室内試験によ り, 岩石の乾湿繰返しによる強度低下の多くは初期サイ クルで大きく低下し，その後は極めて緩やかに低下寸る 傾向があることを示した．板橋ら ${ }^{11} は ，$ 高サイクルの室 内スレーキング試験を行い，スレーキング材料の沈下の 原因が粒子破砕であることを述べている．菊本ら ${ }^{12} /$ は， 破砕した泥岩の室内試験より，スレーキングに伴う細粒 化は土の力学特性に不可逆な変化をもたらすことを述べ, また, 拘束応力下で乾湿履歴によって発生するスレーキ ングは土の大圧縮を引き起こすことを指摘した. これら は，室内試験により地盤材料のスレーキング現象と応力 ひずみ特性について検討したものである。しかし，それ らの集合体である盛土本体の変質についての研究は少な い. 山辺ら ${ }^{13}$ は, 全国の高速道路のうち 11 路線の 26箇 所の盛土で行った原位置試験結果から, 脆弱岩盛土が経 時的に軟質化したことを推察している. 中村・小林 ${ }^{14}$ は, 供用中の脆弱岩盛土で行った原位置試験および室内試験 結果から, 盛土内の飽和度や含水比が高くなっているこ とを示し, 盛土体の強度低下を指摘している. 長尾ら ${ }^{15}$ は，降雨による高速道路のり面の被災状況について，地 形や地質・盛土材料に着目して分析を行っており，盛土 のり面では集水型傾斜に構築された脆弱岩盛土で被災が 多いことを報告している.

この様に，スレーキング性の岩石を地盤材料として有 効に利用するための研究が進み, 密実な締固めを行い含 水比が変化しない様な施工管理が行われてきたが，構築 された盛土は経時的に細粒化が進行し, 盛土体の沈下や 強度低下が発生している．また，良質な地盤材料で構築 された盛土と異なり, 脆弱岩盛土は経時的に劣化するた め供用中の性能維持が課題となっている.

\section{3. 変状した脆弱岩盛土の概要}

\section{(1) 当該盛土の位置と概要}

当該盛土は, 秋田自動車道の秋田中央 IC の北側に位 置し, 沖積平野からなる平坦な区間から丘陵地の区間に 変遷する位置で, 起・終点側が切土構造となる谷埋め盛 土区間である（図-1，図-2，図-3）。この区間は，3 条 の沢地形が合流する地点で, のり尻部で沢の出口が狭ま るボルトネック状の地形であった。 盛土は傾斜地盤上に 構築しており, 山側となる下り線側は盛土高が約 $1 \mathrm{~m}$ で あるのに対し，谷側となる上り線側の盛土高は約 $16 \mathrm{~m}$ で腹付け盛土の形状であった。 また，盛土材料は，当該 区間と隣接する切土区間の掘削により発生した現地発生 土のシルト岩を利用しており，盛土施工時(1995 年) 空 気間隙率は $15 \%$ 以下で密な締固め管理を行っていた.

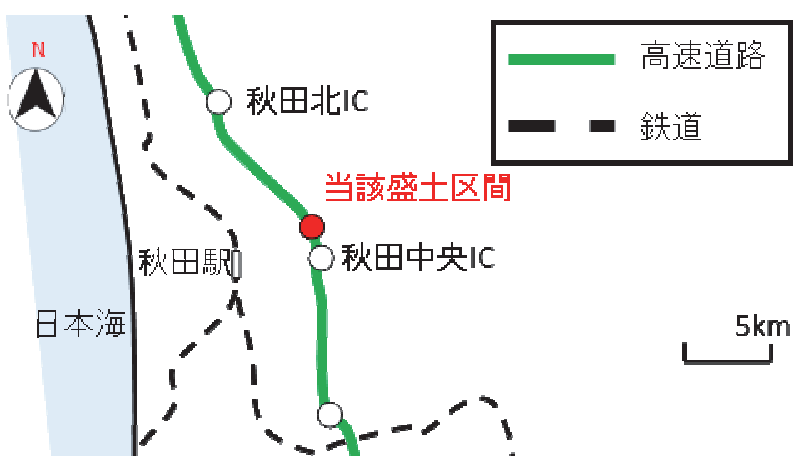

図-1 当該盛土区間の位置図

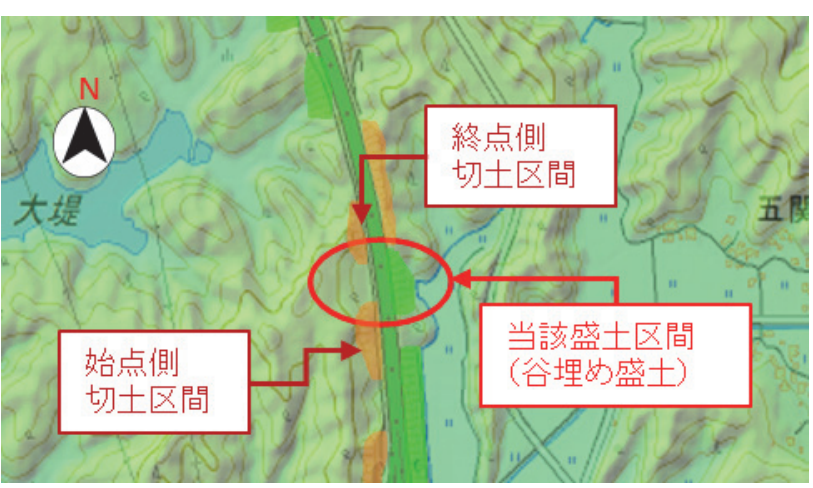

図-2 当該盛土区間の位置図（詳細）

2002 年 3 月に路面クラックが発生し, ボーリング調査 （2 孔）やレーダー探査による路面下の空洞調查が行わ れ, 舗装面下に小規模な空洞や緩みが確認された. その 後も, 断続的に路面クラックが発生し, その都度, クラ ック補修が行われてきた. 2012年 4 月は路面に発生した クラックに拡張が生じたことから，ボーリング調査（3 孔）と動態観測（地下水位計・パイプひずみ計）を実施 した. 2012年 12 月・2013 年 3 4 月に応急対策として水 抜きボーリング工，2013 年 11 月〜翌年 4 月に恒久対策 工（かご枠工・砕石竪排水工）を行った以降は, クラッ クの発生はない. 2002 年と 2012 年のボーリング調査は, 盛士状況・水位変動・す心゙り面位置の把握を目的に実施 され，盛土材の経時変化は考慮していなかった，そこで, これらの既往資料（施工時の材料意見結果・2002 年度 と 2012 年度の地盤調查結果) を基に, 脆弱岩盛土の物 性変化に着目し, データを再整理した。

\section{（2）当該盛土の施工時（1995 年）の物性}

盛土の施工期間は 1995 年 8 月下旬〜 11 月下旬で，そ の当時の盛土材の物理特性を表-1 に示す. なお，土の 液性限界・塑性限界試験（JIS A 1205）は裏ごしによっ て目開き $425 \mu \mathrm{m}$ のふるいを通過した試料を用いるため, 採取した岩砕試料の中でも細粒分を使用したと推測でき， そのために比較的活性の高い粘土と同様な值となったと 推察する. 岩の破砕試験およびスレーキング試験は, 試 


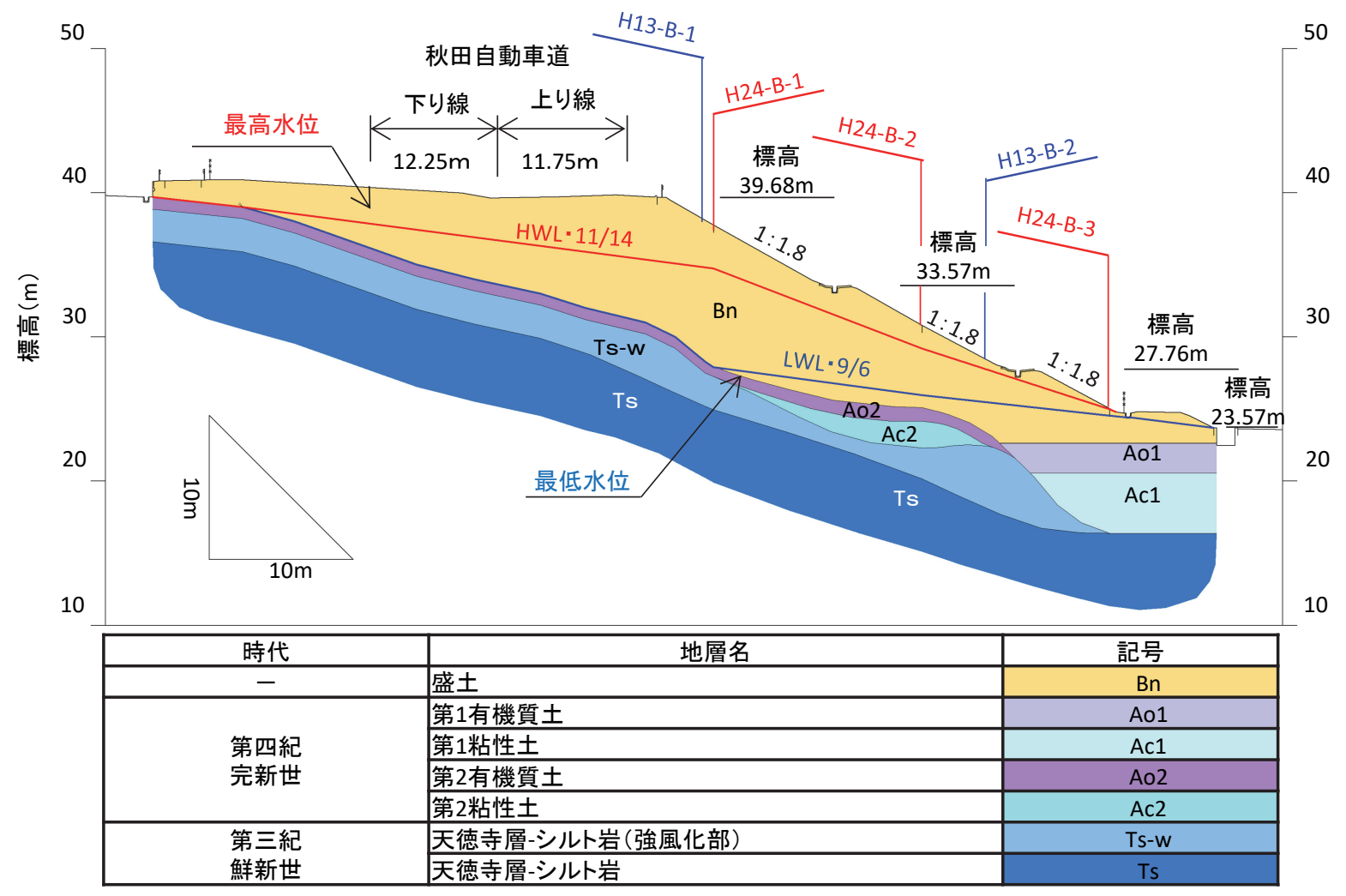

図-3 推定地質横断図

表-1 盛土材の物理特性（盛土施工時（1995 年））

\begin{tabular}{|lll|c|c|c|c|c|c|c|c|c|c|c|}
\hline 試料番号 & & & 01 & 02 & 03 & 04 & 05 & 06 & 07 & 08 & 09 & 10 & 11 \\
\hline 自然含水比 & $W_{n}$ & $\%$ & 38.2 & 37.5 & 38.0 & 54.2 & 33.6 & 51.9 & 37.4 & 42.3 & 38.9 & 41.9 & 53.4 \\
\hline 比重 & $G_{S}$ & & 2.567 & 2.576 & 2.563 & 2.573 & 2.556 & 2.572 & 2.549 & 2.529 & 2.538 & 2.531 & 2.602 \\
\hline 液性限界 & $W_{L}$ & $\%$ & 61.8 & 62.7 & 61.3 & 61.9 & 61.9 & 62.6 & 62.3 & 61.8 & 62.4 & 62.5 & 77.2 \\
\hline 塑性限界 & $W_{P}$ & $\%$ & 44.3 & 43.6 & 42.8 & 42.3 & 43.7 & 44.3 & 44.5 & 43.7 & 44.1 & 43.4 & 41.8 \\
\hline 塑性指数 & $I P$ & & 17.5 & 19.1 & 18.5 & 19.6 & 18.2 & 18.3 & 17.8 & 18.1 & 18.3 & 19.1 & 35.4 \\
\hline 最大乾燥密度 & $\gamma_{d}$ & $\mathrm{~g} / \mathrm{cm}^{3}$ & 1.367 & 1.416 & 1.307 & 1.012 & 1.115 & 1.075 & 1.355 & 1.257 & 1.336 & 1.252 & 1.129 \\
\hline 最適含水比 & $W_{\rho p}$ & $\%$ & 24.6 & 21.2 & 23.0 & 28.4 & 36.2 & 22.0 & 24.6 & 28.6 & 24.2 & 27.8 & 39.5 \\
\hline 岩の破砕率 & & $\%$ & - & - & 40.5 & - & 40.2 & - & 41.3 & - & 40.0 & - & - \\
\hline スレーキング率 & & $\%$ & - & - & 100.0 & - & 73.8 & - & 92.6 & - & 100.0 & - & - \\
\hline 細粒分含有率 & $F_{C}$ & $\%$ & - & - & - & - & & - & 43.5 & - & 45.9 & 64.1 & - \\
\hline
\end{tabular}

料番号 03，05，07，09 の 4 試料で実施された.この結 果，破砕率が $40 \%$ 程度，スレーキング率が概水 $90 \%$ 以

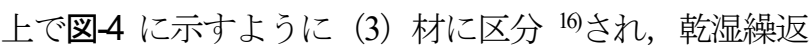
しに伴うスレーキングの進行で影響を受けやすい材料で あることがわかる，なお，図中の（1）材はスレーキン グ率が 30\%未満の材料でスレーキングによる体積圧縮 等の影響が小さい，それに対し，（2）材および（3）材 はスレーキング率が $30 \%$ 以上の材料で, 盛土完了後の 圧縮沈下を軽減するため締固めは空気間隙率 $15 \%$ 以下 とすることが望ましい．特に，（3）材は破砕率が低く 最も圧縮沈下が㲘念される材料である.

図-5 は，施工時（1995 年）における盛土材の粒度分 布で，土砂分と破砕された軟岩に区分されている．この
図中の試料番号に対する自然含水比は軟岩（試料番号; 07・09）で 37.4 38.9\%，土砂（試料番号；10）で 41.9\% を示し, 細粒分の含有が多い土砂で自然含水比が高い.

図-6 は，当時の施工記録から各巻出し厚における空気 間隙率と施工含水比をまとめたものである. 盛土施工時 の空気間隙率 $V_{a}$ は概ね $10 \%$ 以下で $15 \%$ よりも低く, 非 常に密に締固めて盛土施工していることがわかる．また， 施工時の含水比 $W_{n}$ は $34.5 \sim 41.5 \%$ 程度で, 一般的な泥岩 の含水比である $34.6 〜 46.4 \%$ 苚 と同程度であった.

(3) 盛土変状と素因 · 誘因

a) 変状の状況

前述したように当該区間は 1995 年に盛土施工が行わ 


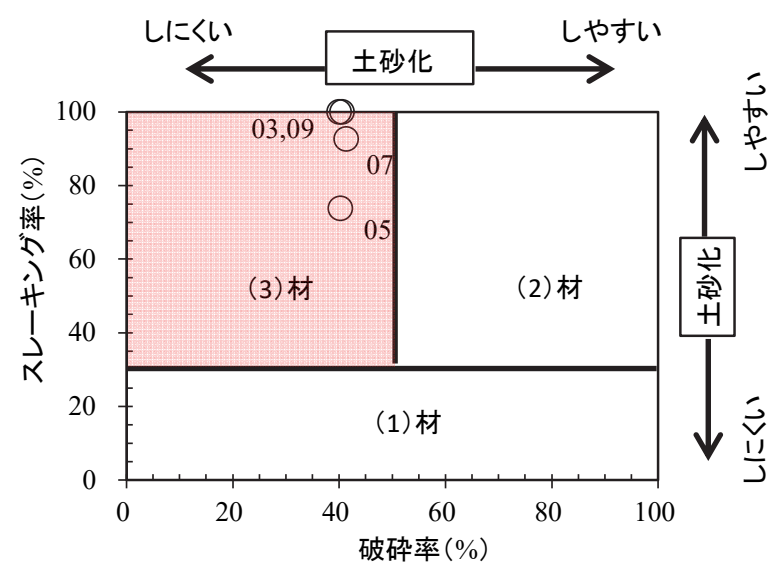

図-4 スレーキング性材料の区分 文献 16)に加筆

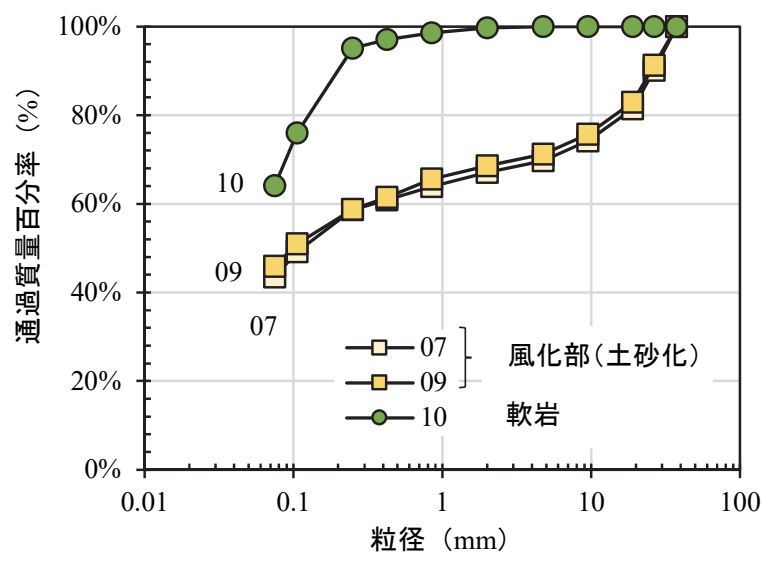

図-5 施工時（1995 年）の粒度分布

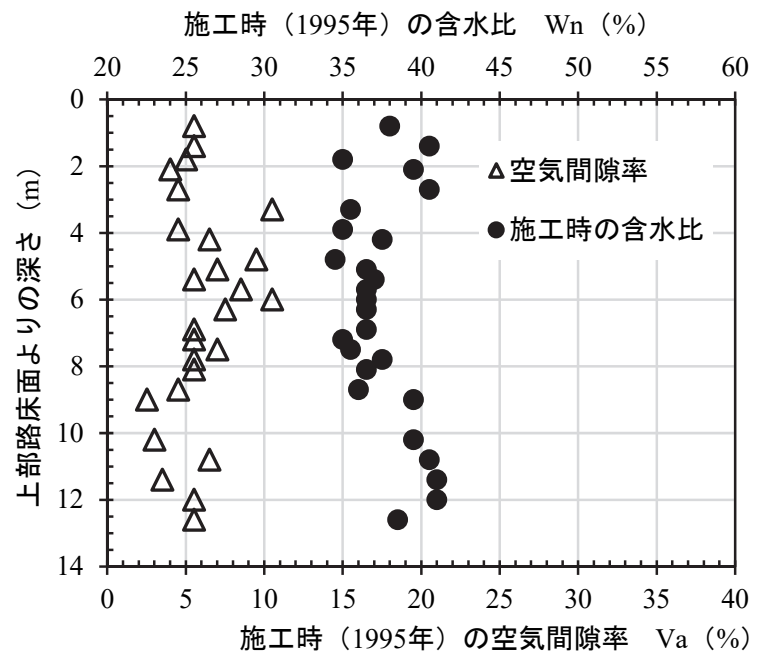

図-6 各巻出し厚における空気間隙率と施工含水比

れ，1997年 11 月 13 日より供用が開始されている．その 3 年 4 ヶ月後の 2001 年 3 月下旬に舗装面にクラックが確 認され，ボーリング調査およびレーダー探査により舗装 面下の空洞調査を実施した。レーダー探査は，電磁波

(400MHz の超短波) をアンテナから地中に向けて発信 し，地盤内の反射波を受信して，その到達時間から反射 対象物の深度を測定を行った．またここのアンテナを舗
装面に沿って移動（下り線・縦断方向に 11 測線）させ ることにより，面的な分布を計測した．なお，舗装面は オーバレイ工による補修を行っている.

図-7 は，舗装面に発生したクラックとレーダー探査 で推定した緩みや空隙の箇所を示している.これより， 舗装面に発生したクラックを包括するように，舗装面下 にはゆるみや空隙が発達していたことがわかる．その後 も断続的に舗装面にクラックが発生し，その都度オーバ レイ工による補修が行われていた。 2012年 4 月 3 日の巡 回点検時に，クラックが舗装面に発生しているのを発見 した。定点を設けクラック幅の計測を実施した結果, 4/3 4/18 の 15 日間で $8 \mathrm{~mm}$ のクラック拡張を確認した. 直ちにボーリング調査（3 孔）を行い，H24-B-1 と H24 B-2 の 2 孔に動態観測システム (パイプひずみ計・自記 水位計）を構築し，常時監視体制を整えた. なお，パイ プひずみ計のセンサーは深度 $1 \mathrm{~m}$ より $1 \mathrm{~m}$ 間隔で各観測 孔の孔低深度まで設置している。同年 10 月中旬から 11 月下旬までにかけて発生した比較的連続した降雨により, 11 月 14 日に舖装面に新たなクラックが発生した（図8).

\section{b) 動態観測結果}

動態観測結果から，この比較的連続した降雨期間に H24-B-1 と H24-B-2 の両孔で孔内水位が上昇するととも に，パイプひずみ計で累積性の残留ひずみが観測された. H24-B-1 の観測結果を図-9 に示す. 2012 年 7 月 4 日より 観測を開始し, 同年 12 月 31 までの最低水位は深度 9.85m（9月 4 日）で盛土と旧地盤面である粘性土の境界 付近であった。 10 月 11 日から比較的連続した降雨がみ られ，孔内水位の上昇が顕著化し，10月 30 日に孔内水 位が標高 $33.49 \mathrm{~m}$ に達した後, パイプひずみ計の深度 $11 \mathrm{~m}$ と $12 \mathrm{~m}$ の 2 深度のみに累積性のひずみが発生した。 11 月 13 日に $66.5 \mathrm{~mm}$ (日降水量) の降雨により, 翌日の 11 月 14 日に最高水位 $34.74 \mathrm{~m}$ （深度 $3.01 \mathrm{~m}$ ）に達し， 12 月 1 日まで孔内水位は高水位で小康状態であったが，そ の後の降雨の減少により孔内水位も漸減しはじめ, 12 月 11 日に孔内水位が標高 $33.00 \mathrm{~m}$ まで低下寸るとひずみ の累積も停止した、ひずみの発生位置は盛土直下の風化 シルト岩内であった。 なお，ボーリングコア観察でも深 度 $10.90 \mathrm{~m}$ 付近に軟質な粘土を確認し, 同深度をすべり 面と判断した（写真-1）.

\section{c) 変状の発生要因}

H24-B-1 と H24-B-2 で行った地下水検層では，盛土と 表土の境界付近で比抵抗值の変化が顕著で，地下水が流 入していることがわかる（図-10）。前述した最低水位 も同程度の深度であり, 盛土内に浸透する水は, 表面水 や浸透水が盛土山側の谷地形から盛土と旧表土の境界を 流下寸るとともに盛土内に浸透し, 盛土内の水位が変化 すると考える. 表-2に変状の発生要因をまとめる. 


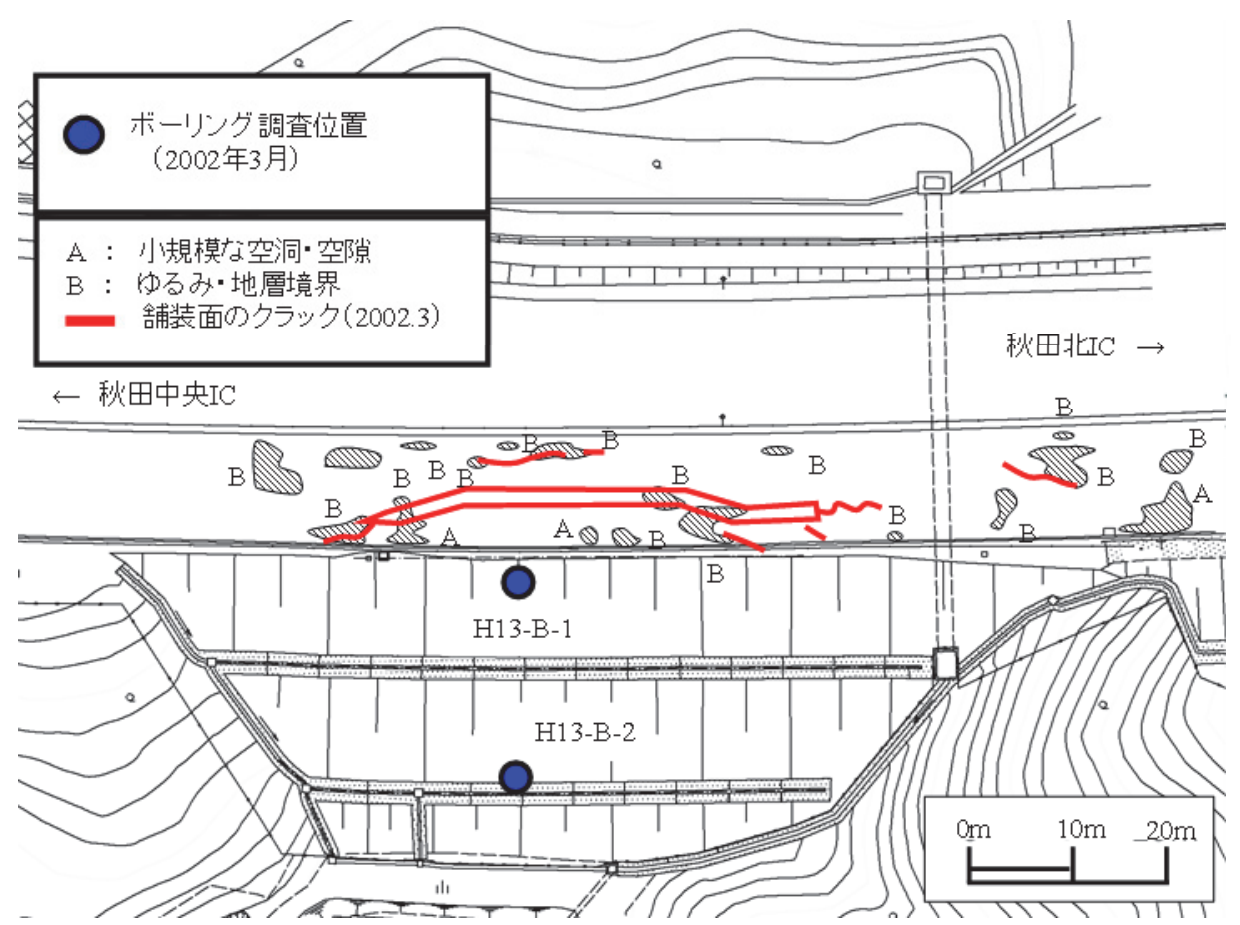

図-7 2001年 3 月の変状状況

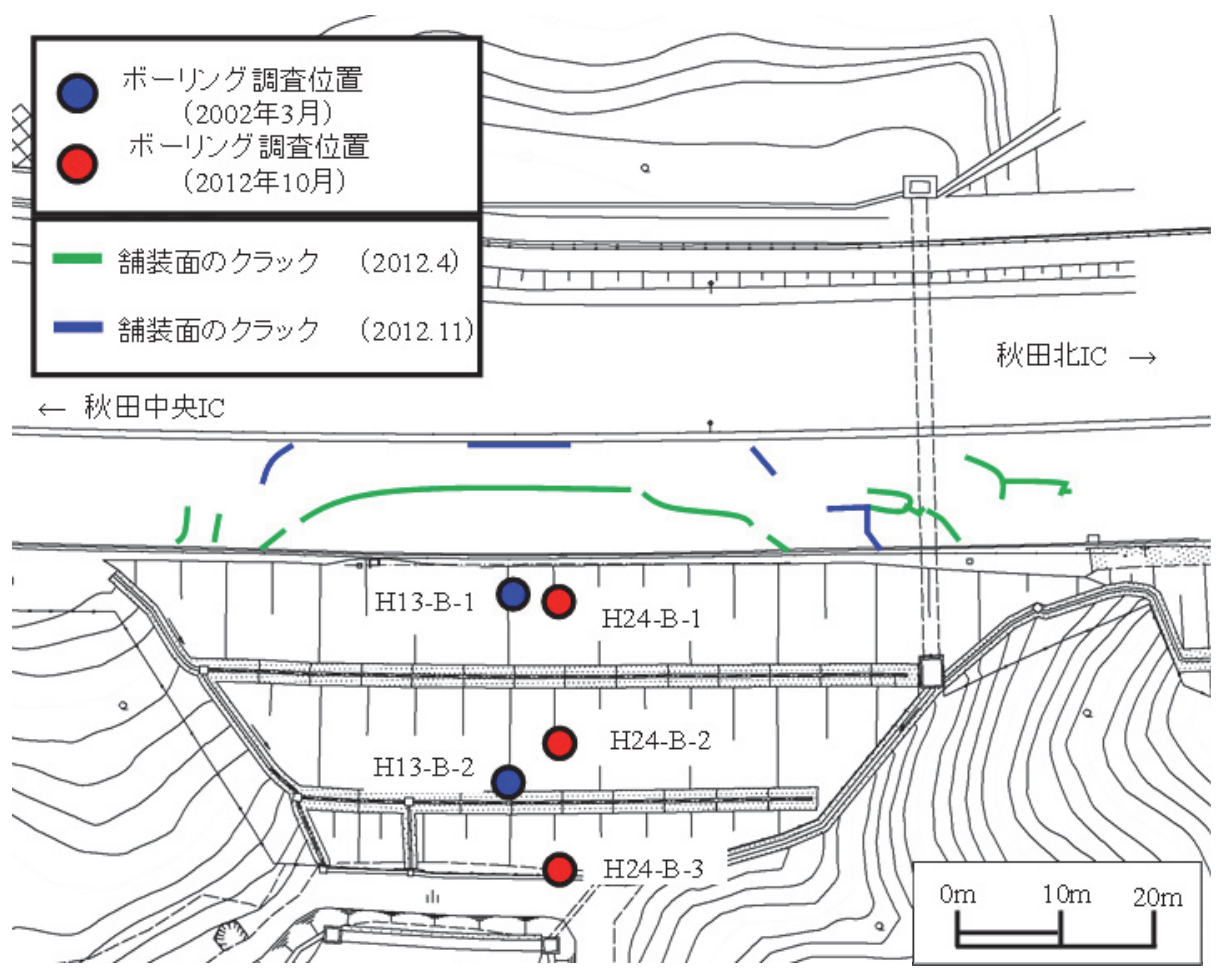

図-8 2012年 4 月・11月の変状状況

当該区間の盛土変状の特徵として，低水位ではひずみ の累積や舗装面にクラックは生じていないが，高水位で 累積性のひずみや舗装面にクラックが生じたことが挙げ られる，このようなことから，盛土体内の水位上昇を抑 制する目的で地下水排除工を主対策とした応急対策（水 抜きボーリング工）を同年 12 月と翌年 3 月に合計 22 本 実施した。恒久対策は盛土のり尻付近の補強と排水性の

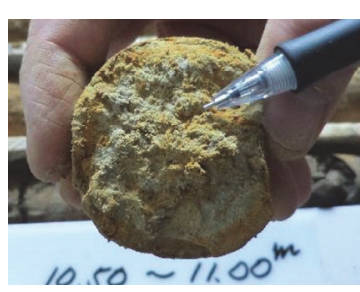

GL- $10.65 \mathrm{~m}$ 付近 : 風化シルト岩 原岩組織を残す

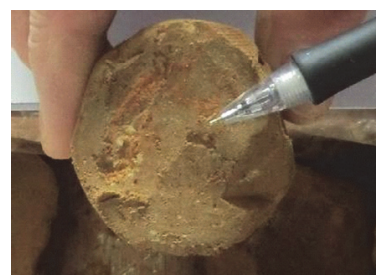

GL-10.90m 付近 : 風化シルト岩 粘土化·軟質化が顕著
写真-1 すべり面付近のコア状況（H24-B-1） 

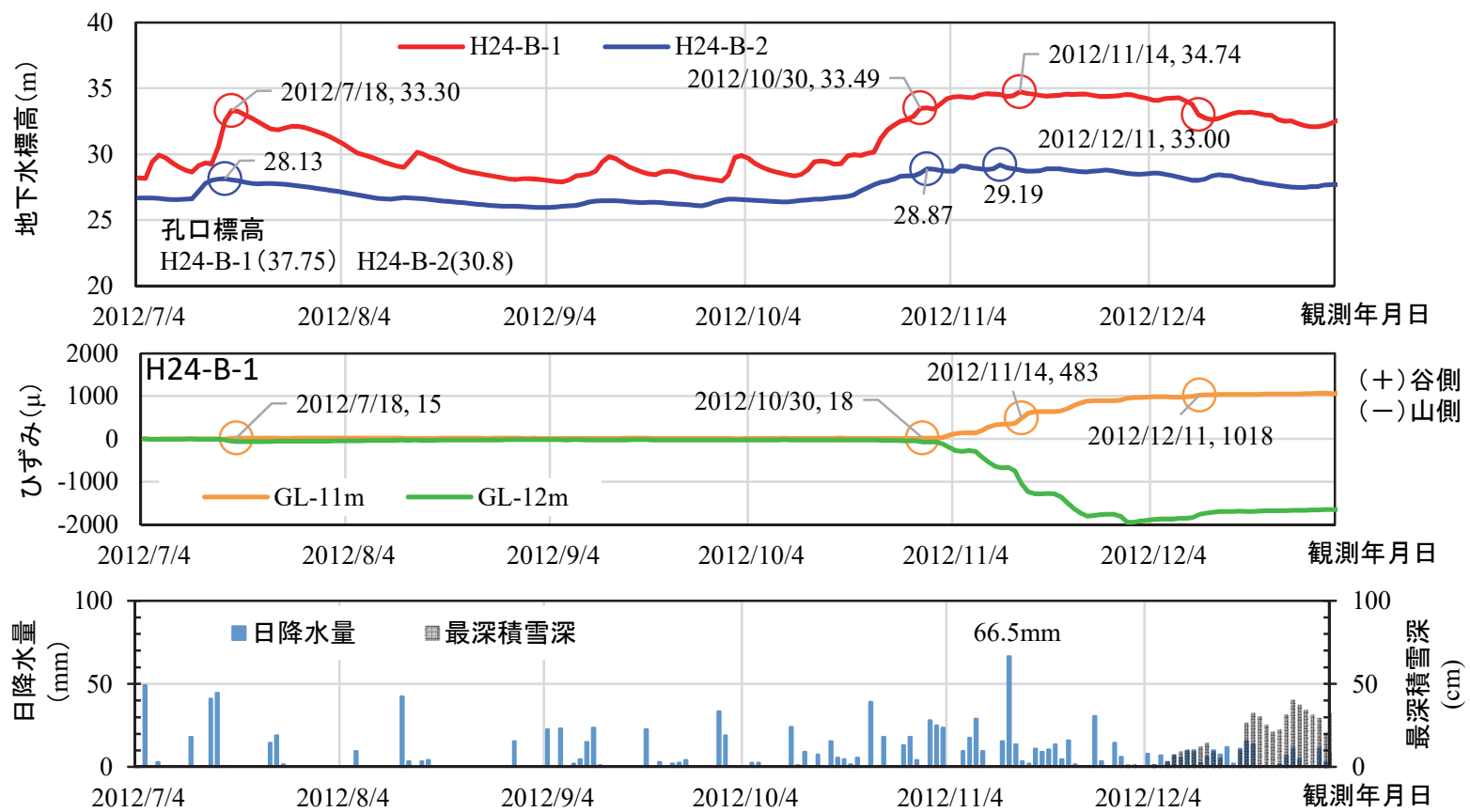

図-9 水位とひずみの変化
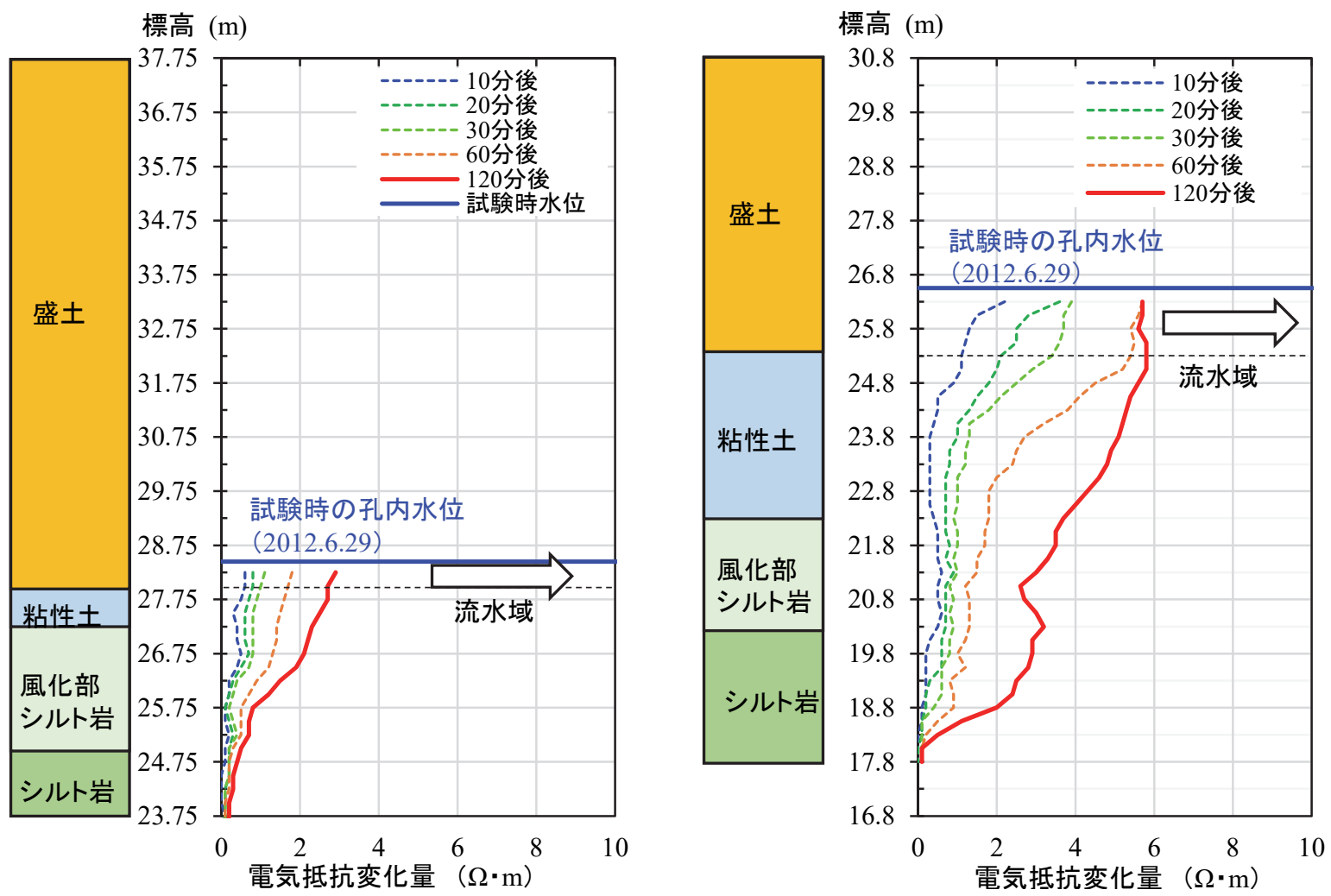

図-10 地下水検層結果（左 : H24-B-1，右 : H24-B-2)

向上を目的として，かご枠工と砕石竪排水工を追加実施 した（図-11）。恒久対策工事完了から 1 年間経過観察 を行ったが，融雪期や降雨後の盛土体内の水位上昇が抑 制され，融雪期や連続的な降雨後にも累積性のひずみは 発生していない.

\section{4. 盛土材の物性変化}

\section{(1) $\mathrm{N}$ 値}

まず， 2002 年 3 月と約 10 年後の 2012 年 6 月に行った ボーリング調査で実施した $\mathrm{N}$ 值を比較する。図-12 は, 盛土内で行った標準貫入試験結果を実施年毎に色分けを 


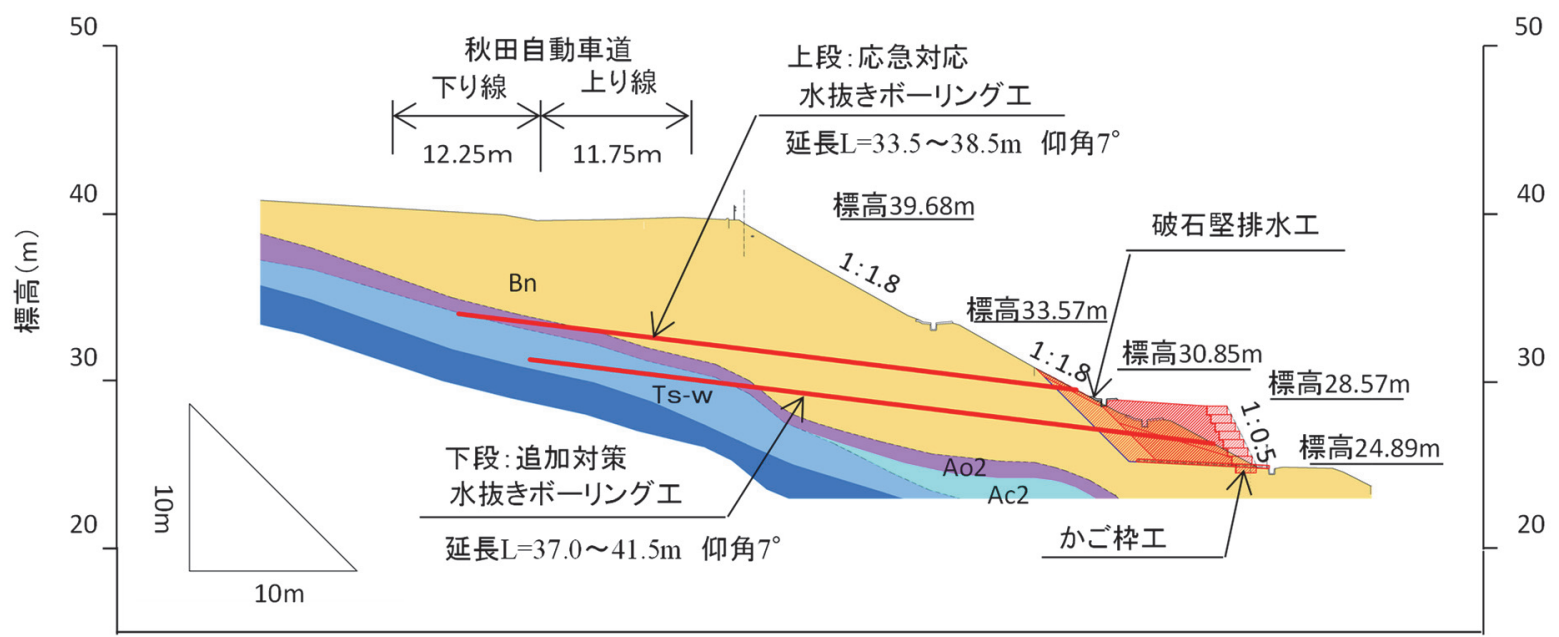

図-11 当該区間の対策工模式図

表-2 路面変状が発生した要因

\begin{tabular}{|c|c|}
\hline \multirow{4}{*}{$\begin{array}{l}\text { 地形・材料 } \\
\text { に関する要因 }\end{array}$} & ·3 条の旧沢地形が合流する集水地形 \\
\hline & •ボトルネック状の狭隘部に位置する谷埋め盛土 \\
\hline & ·スレ一キング性のシルト岩起源の盛土材料 \\
\hline & •スレーキングが進行し盛土材は粘性土状を呈す \\
\hline \multirow{4}{*}{$\begin{array}{c}\text { 地下水 } \\
\text { に関する要因 }\end{array}$} & ·降雨後に水位上昇する \\
\hline & ·2012 年 4 月のクラック拡張は融雪期 \\
\hline & ·2012 年 11 月のクラック拡張は断続的な降雨時 \\
\hline & ·水位の変動とひずみ変化に関連性がみられる \\
\hline
\end{tabular}

して整理したもので，左図は標高，右図は各部位におけ る $\mathrm{N}$ 值の出現頻度を示している。 なお，2012 年に $\mathrm{N}$ 值 が 8 を示す 2 点は，それぞれ H24-B-1 と H24-B-2 の深度 1.15 1.45m 間の值である. 2002 年と 2012 年を比較する と, 10 年間で各標高の $\mathrm{N}$ 值は全体的に 1 程度低下して いる.

脆弱岩のスレーキング現象には，乾燥・湿潤の影響が 大きいことから，図-12 示すように（イ）水位の変動差 が大きい “盛土のり肩付近のグループ (H13-B-1 と H24 B-1）”，（口）水位の変動差が小さい“盛土のり尻付 近のグループ（H13-B-2，H24-B-2 および H24-B-3）”の

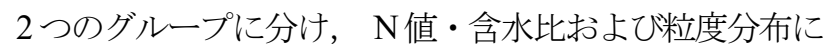
ついて各部位の経時的変化を検討した.

\section{(2) 自然含水比}

自然含水比は，施工時（1995 年）の材料試験と 2002 年 3 月と 2012 年 6 月に行った室内土質試験で観測した. 図-13 は，サンプリング標高毎の自然含水比を測定した 年毎に色分けをして示したものである. 2002 年と 2012 年で盛土内で含水比は一様でない. なお，施工時（1995
年）の含水比の範囲は図-6 で示した值の範囲である.

調査した季節が異なるため単純な比較はできないが, 施工時, 2002 年および 2012 年の含水比を比較すると, 施工含水比は $34.5 \sim 41.0 \%$ であったが 2002 年には標高 $25 \mathrm{~m}$ より上位では $48.9 \%$ （中央值）となっており最大施 工含水比より $7.9 \%$ 増加していた. なお, 標高 $25 \mathrm{~m}$ より 下位では最大施工含水比と同程度で変化は乏しい. 2002 年から 2012 年では, 標高 $25 \mathrm{~m}$ より上位の中央值は 48.9\%から 45.8\%へ変化しており 3.1\%減少していたのに 対し，標高 $25 \mathrm{~m}$ より下位では $41.3 \%$ から 44.7\%へ変化し $3.4 \%$ 増加がみられてる. なお, 標高 $25 \mathrm{~m}$ は盛土のり 尻の標高と同程度である.

\section{(3) 粒度分布}

スレーキングの進行により盛土材の団粒化も懸念され るが，既往調査では土の粒度試験は JIS A 1204 に準じて 実施されている点に留意願いたい。また，2002 年と 2012 年の粒径 $75 \mu \mathrm{m}$ 未満は沈降分析結果の比較であり, 加水の影響を受けている可能性があるが，同一条件下の 比較として整理する．試験試料は，標準貫入試験で採取 した試料を用いているため, 粒径が大きい砂は採取でき てない可能性がある. 今回は, 砂分と細粒分の変化に着 目し, 礫分（粒径 $2 \mathrm{~mm}$ 以上）を除き整理している.

図-14 は，1995 年（施工時）・2002 年 3 月および 2012 年 6 月の盛土の粒度分布を盛土のり肩付近と盛土のり尻 付近に分けて示したものである. まず 2002 年および 2012 年ともに, 1995 年（施工時）と比べ細粒分の割合 が増加しており，その傾向は盛土のり尻付近よりも盛土 のり肩付近て顕著である.

盛土のり肩付近では, 2012 年の粒径 75 $\mu \mathrm{m}$ 以下の割合 が 2002 年より減少している.これは，のり肩付近では, まず，1995 年 (施工時) から 2002 年の間に顕著な細粒 化が生じ，その後 2012 年の 10 年間に細粒分が流出した 

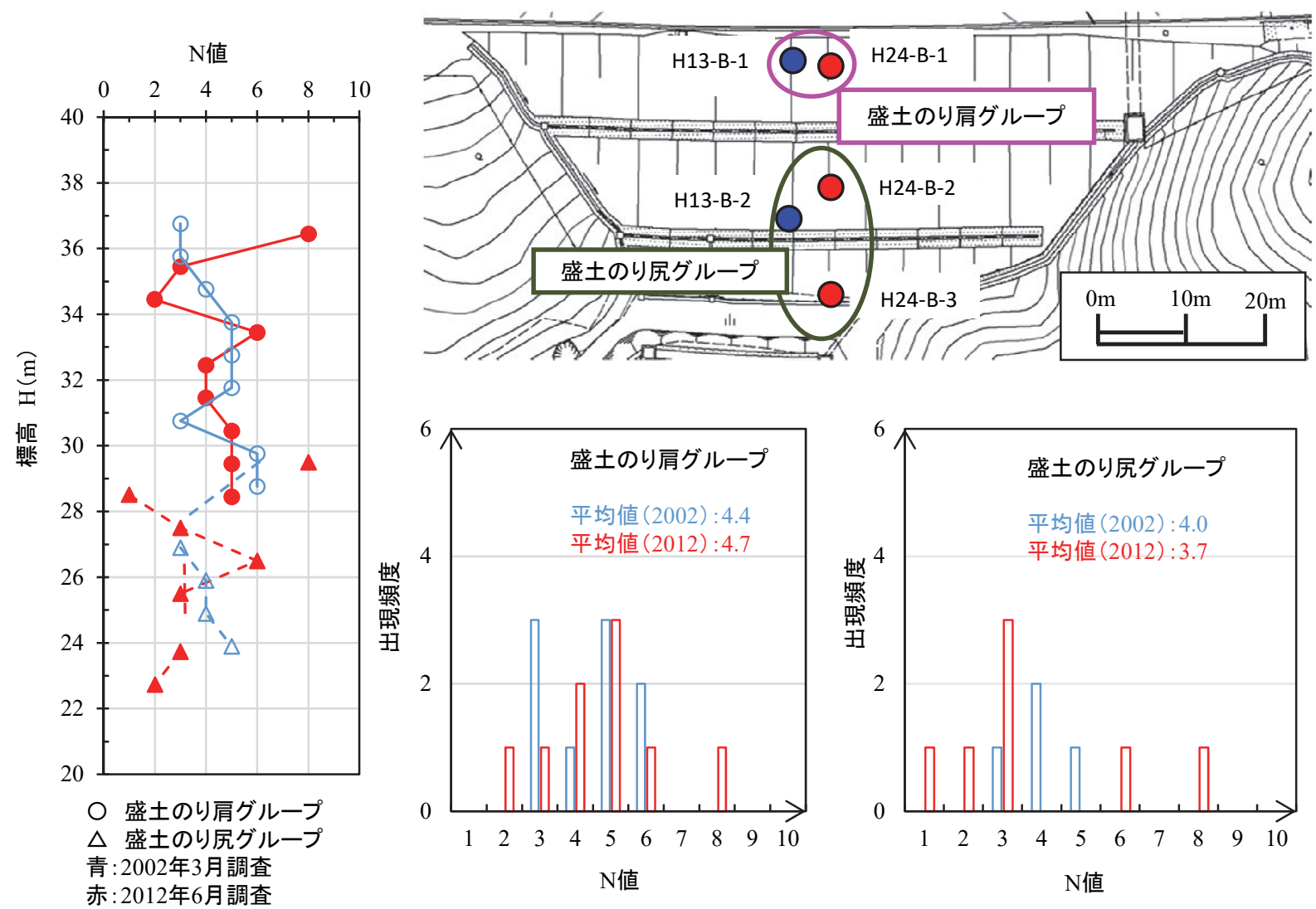

図-12 N值の経年変化状況 (左図 : 標高 上段 : 平面図 下段 : 頻度)

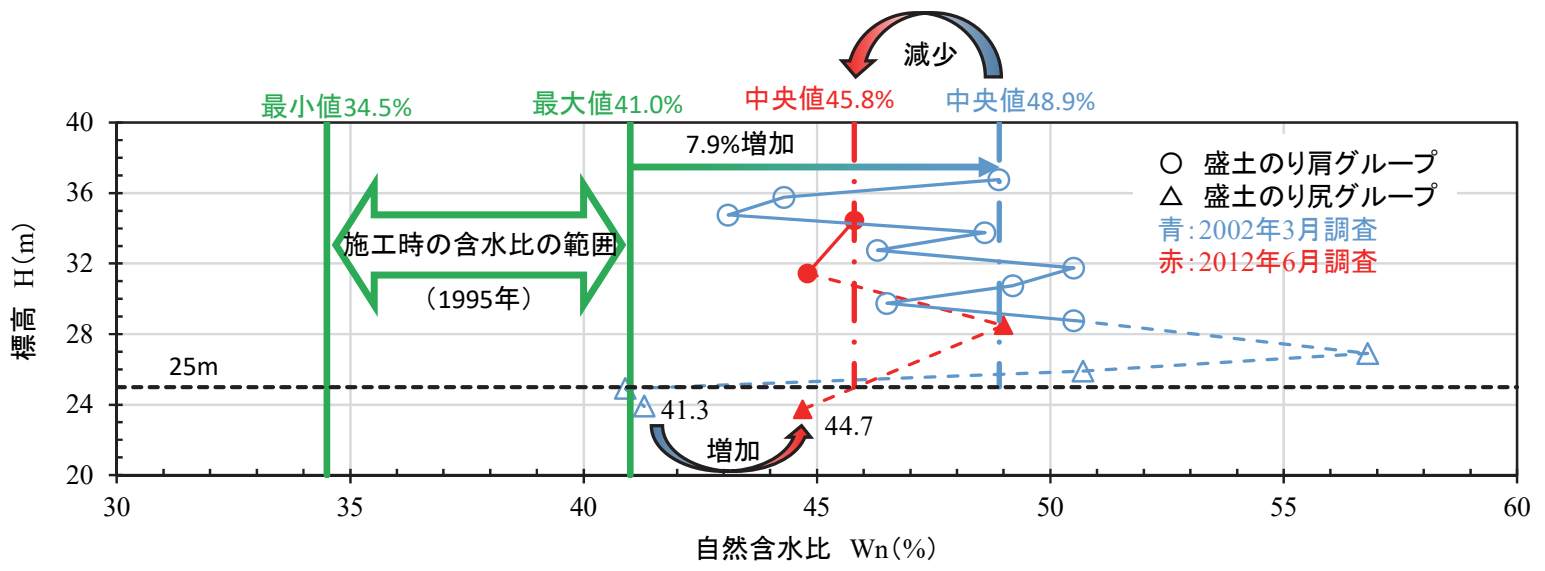

図-13 自然含水比の経時変化状況

ことを示している. このことは，2001年 3 月から路面下 で空洞やゆるみが発見されていることと整合的である. 一方，盛土のり尻付近では，H24-B-2（下方の赤線）で $75 \mu \mathrm{m} \sim 7 \mu \mathrm{m}$ の減少がみられるものの盛土のり肩付近の 状況と比較するとその程度は小さい，また，2012 年の 粒径 $5 \mu \mathrm{m}$ 未満の割合が 2002 年より増加しており, 特に H24-B-3で顕著である.

図-15 および図-16 は各粒度の残留割合をまとめたも のである. 1995 年 (施工時) から 2002 年にかけて粗粒

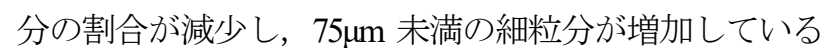
が，盛土のり肩と盛土のり尻はともに同様な傾向を示し，
盛土内の位置の差はみられない. 2002 年から 2012 年へ 経時する中で, $75 \mu \mathrm{m}$ 未満の割合が減少する。ここで, $75 \mu \mathrm{m}$ 未満の粒子の割合に着目すると，盛土のり肩では $5 \mu \mathrm{m}$ 末満の微細粒分が減少するが，最も低位に位置する 盛土のり尻の H24-B-3 では 5 $\mu$ m 未満の割合が増加してお り，2012 年では盛土内の位置と粒度分布に関係性が生 じたことがわかる.

図-17および図-18 は 2002 年と 2012 年の粒径 $5 \mu \mathrm{m}$ 未満 の含有率分布を盛土横断方向で示したものである. 2002 年には盛土の上位で $5 \mu \mathrm{m}$ 未満の含有率が高く，盛土下 方に向かい含有率は漸減する. しかし，その後の 2012 

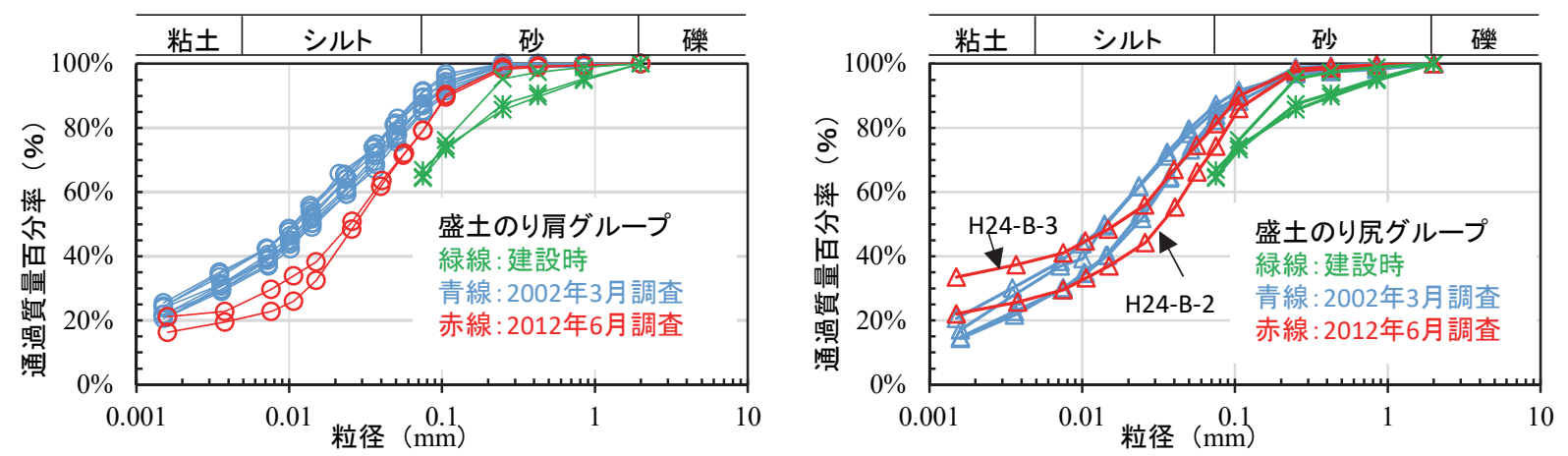

図-14 粒度分布の経時変化状況（左図 : 盛土のり肩グループ 右図 : 盛土のり尻グループ）

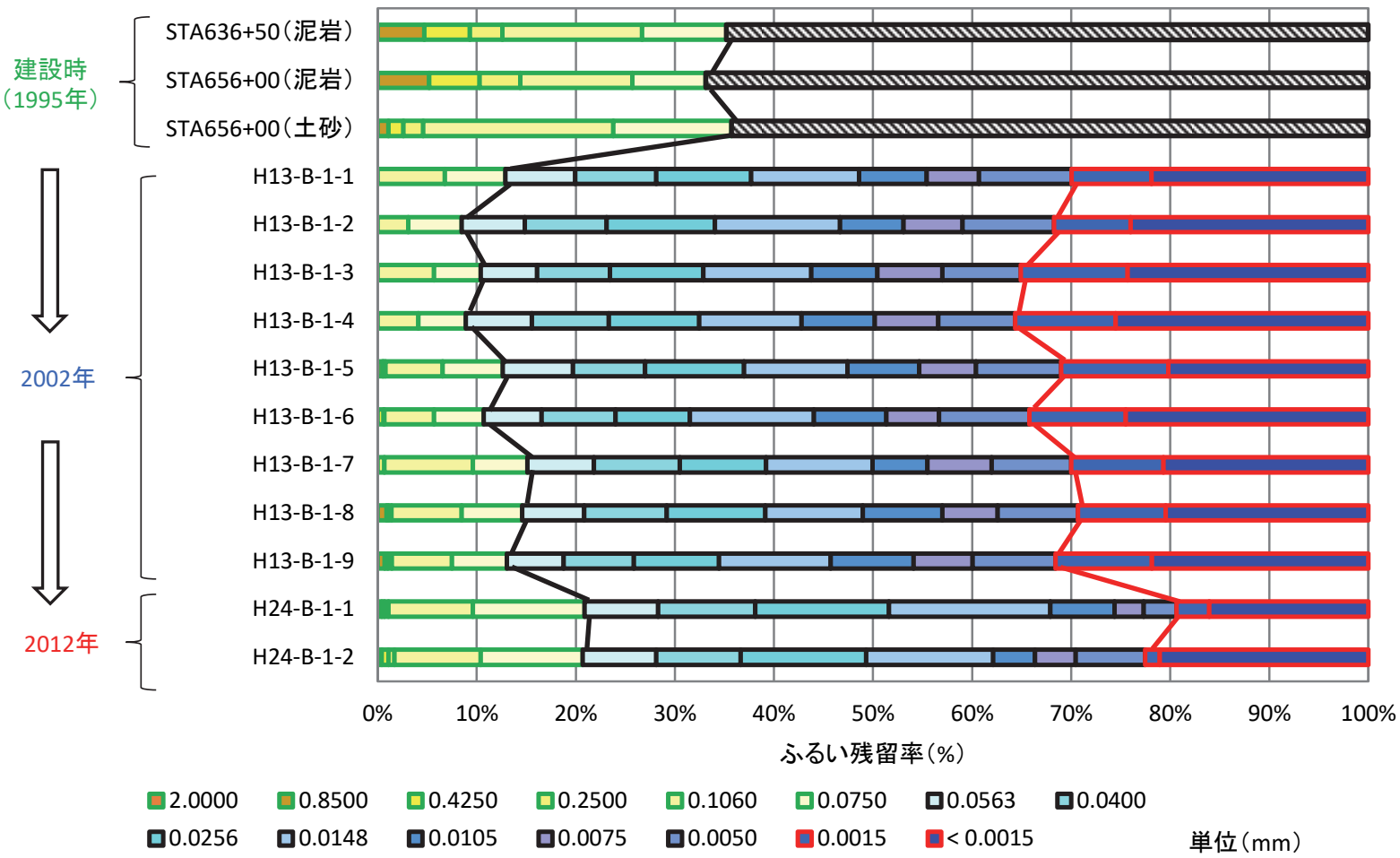

図-15 各粒度のふるい残留率の変化（盛土のり肩）

年には盛土上位の含有率は 2002 年よりも低下し，盛土 のり尻で含有率が増加する。これは，スレーキングによ り発生した細粒分が盛士内の水の移動により，長い時間 をかけ流末方向へ移動することで，盛土のり尻の土粒子 間に蓄積している可能性を示唆する結果である.

\section{(4) 物性の経年変化のまとめ}

a) 空気間隙率が $15 \%$ 以下になるように密実に締め固 めていても，経年的劣化により自然含水比の増 加・細粒分化・N 值は 2002 年と 2012 年を比較する と平均值で 1 程度低下していた。これらは，盛土 上部でスレーキングによって細粒化した細粒分が， その後の雨水浸透によって法尻部に徐々に移動し たことを示しているものと考えられる.

b) スレーキングによる粗粒分の細粒化は，1995 年
(施工時) から 2002 年の初期の期間に多く発生し たが，この現象は特に盛土のり肩付近で顕著であ る.

c) スレーキングにより粒径 $5 \mu \mathrm{m}$ 末満まで微細粒化し た土粒子は，2002 年から 2012 年の間に，地下水の 流下により地下水変動の大きな盛土のり肩付近か ら，盛土内地下水の流末となる盛土のり尻へ移動 したものと考えられる.

d) また，盛土のり尻付近に細粒分が移動することで， 盛土内地下水の流末となる盛土のり尻部の透水性 が低下し，盛土全体の排水性が低下寸ると考えら れる。これにより，細粒分が移動する前と移動す る後では，同じ降雨でおいても後者の方が盛土内 水位が上昇しやすくなると考えられる. 


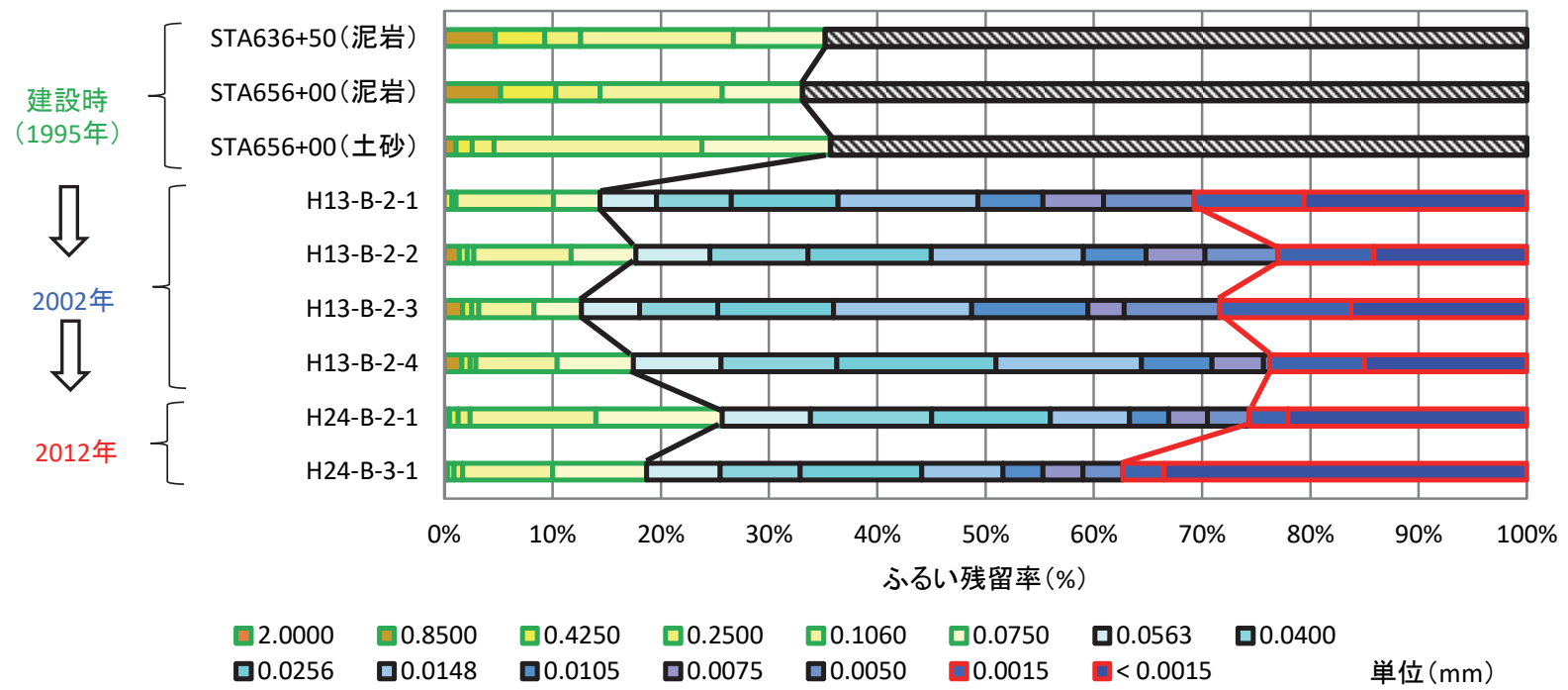

図-16 各粒度のふるい残留率の変化（盛土のり尻）

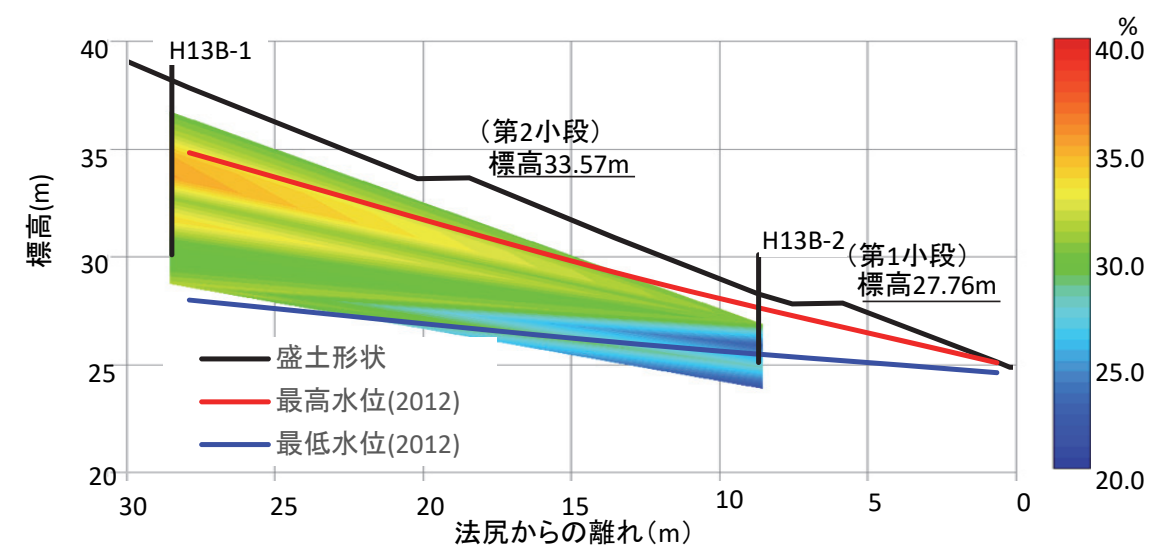

図-17 粒径 $5 \mu \mathrm{m}$ 末満含有率の分布（2002 年）

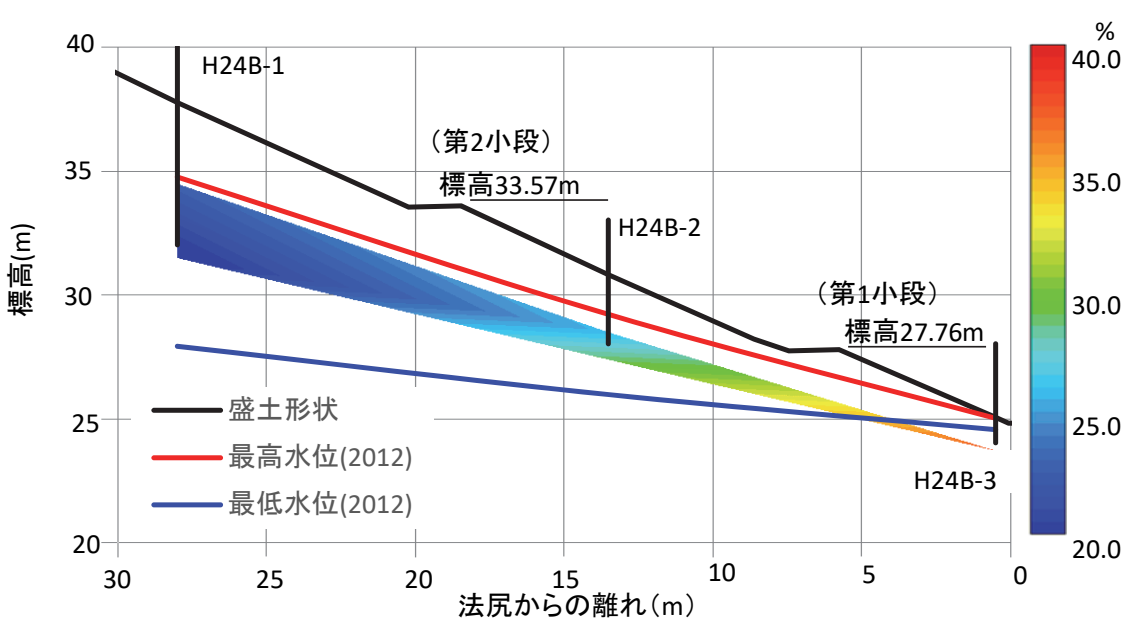

図-18 粒径 $5 \mu \mathrm{m}$ 未満含有率の分布（2012 年）

\section{5. 室内透水試験の結果と考察}

\section{（1） 試料採取状況}

室内試験に用いる脆弱岩試料と盛土試料を，2019 年 に採取した。 なお，脆弱岩試料の採取に先立ち，近接す
る切土のり面および露岩部の現場踏査を行った. 盛土の り面の起点側（南側）に位置する小さな尾根の露岩部は 砂岩であり，シルト岩からなる盛土材料とは異なってい た. 終点側 (北側) の切土のり面の表層を剥ぎ地山を目 視した結果, シルト岩を確認した. 図-19 に示す地質図 


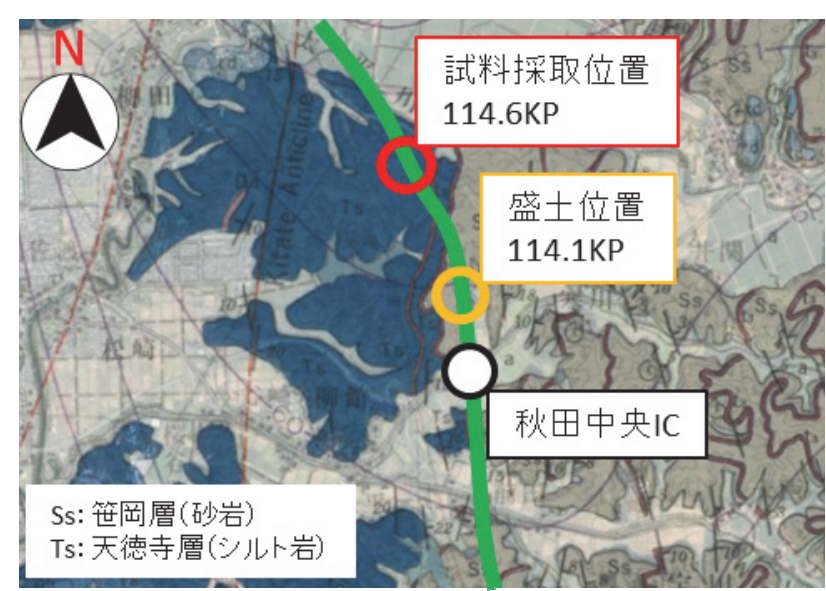

図-19 試料採取箇所位置図 18)に一部加筆

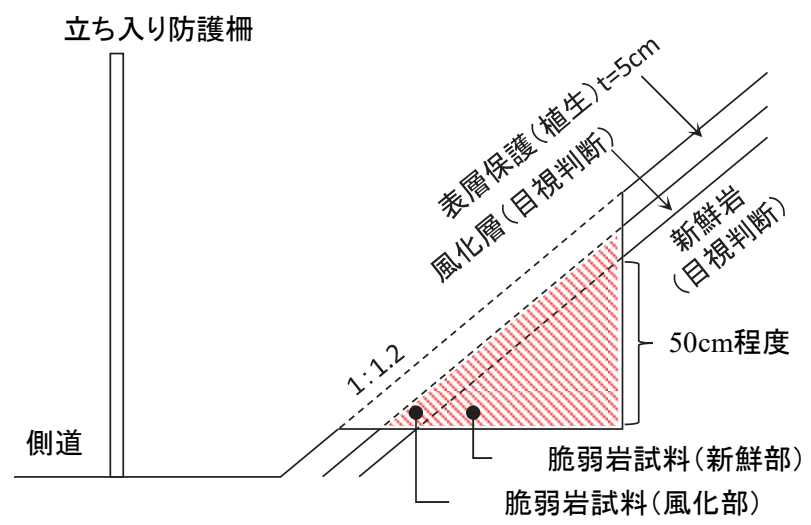

図-20＼cjkstart脆弱岩試料の採取イメージ図

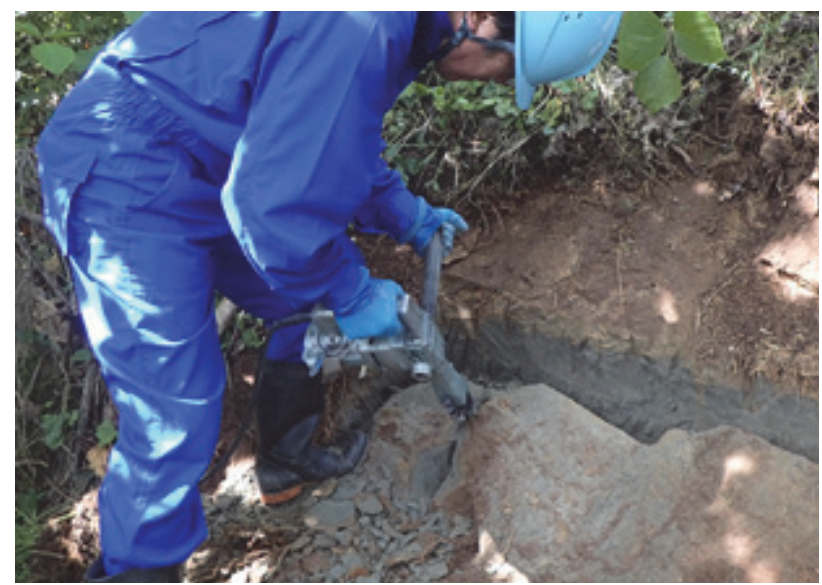

写真-2 脆弱岩試料の採取状況（岩塊サンプリング）

幅とも地山の地質が一致している．シルト岩の試料採取 は，終点側（北側）で確認した切土のり面で行った。試 料の採取は, 写真-2 や図-20 に示寸ように, 人力掘削で 行い, 表層（植生工 $t=5 \mathrm{~cm}$ 程度）を剥ぎ取り，褐色に変 色した風化部と，暗灰色の新鮮な岩を採取した．盛土試 料は，暗褐色の表土を剥ぎ取り，褐色の盛土材を採取し た (写真-3) .

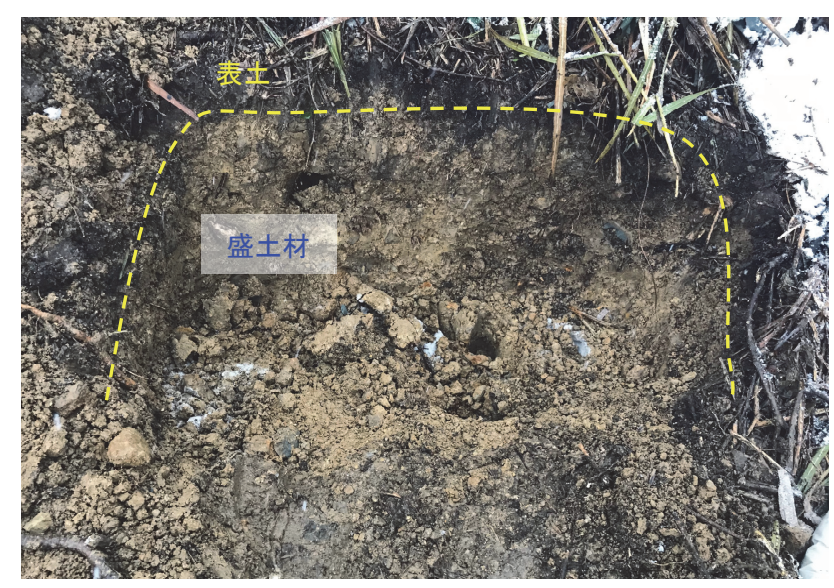

写真-3 盛土試料の採取状況（テストピット掘削）

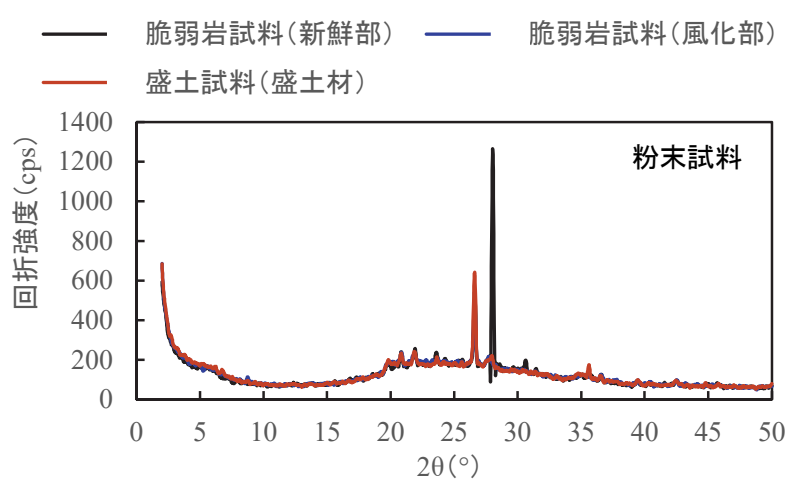

図-21 今回採取した試料の X線回折 (XRD) の結果

表-3 今回採取した試料の $\mathrm{pH}$

\begin{tabular}{|l|l|c|}
\hline \multicolumn{1}{|c|}{ 試料名 } & 区分 & $\mathrm{pH}$ 值 \\
\hline \hline 脆弱岩試料 & 新鮮部 & 4.12 \\
\hline 脆弱岩試料 & 風化部 & 4.89 \\
\hline 盛土試料 & 盛土材 & 4.79 \\
\hline
\end{tabular}

\section{（2）採取した試料の特徵}

採取した盛土と脆弱岩（新鮮部・風化部）の試料の X 線回折（XRD）結果を図-21 に，それぞれの $\mathrm{pH}$ を表-3 にまとめる.

図-21 からわかるように，20=28 近辺（長石のピーク） で脆弱岩試料の新鮮部のみが明膫なピークを示寸のに対 し，脆弱岩試料の風化部と盛士試料にはそれがみられな

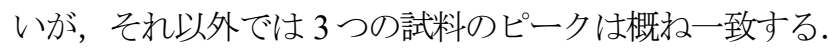
表-3 においても, 脆弱岩の新鮮部がやや低い $\mathrm{pH}$ 值を示 すものの，風化部と盛土部は概水同じ $\mathrm{pH}$ 值を示す。こ れらの事から, 脆弱岩の風化部と盛土材の性状は一致し,

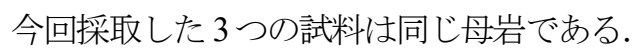

\section{(3) 室内透水試験結果}

隣接切土のり面から採取した岩塊試料を，1995 年 (施工時)・2002 年および 2012 年（盛士のり尻）の粒 度分布に調整した供試体を作成し，飽和状態で室内透水 

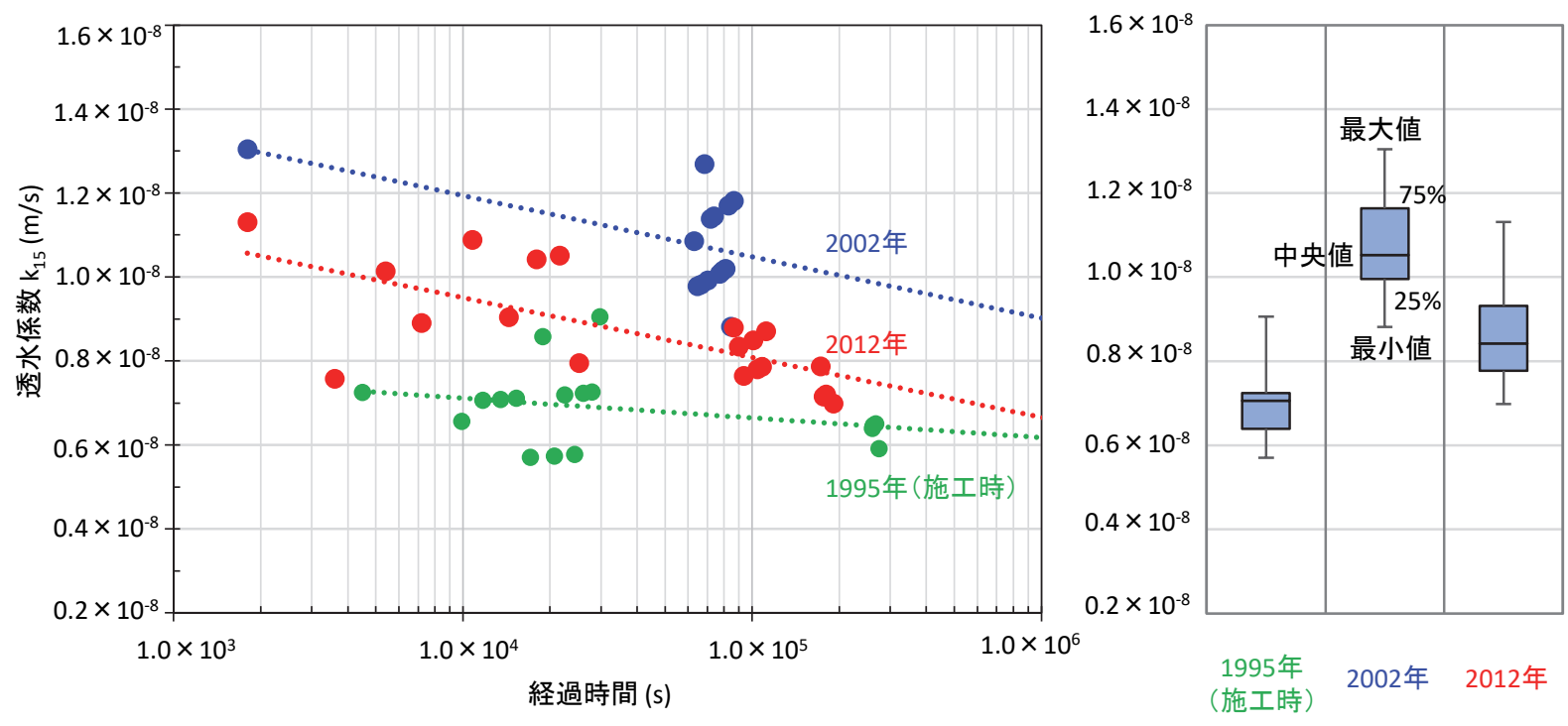

図-22 透水係数の変化

赤字: 試験後に $1 \%$ 以上増加 青字: 試験後に $1 \%$ 以上減少

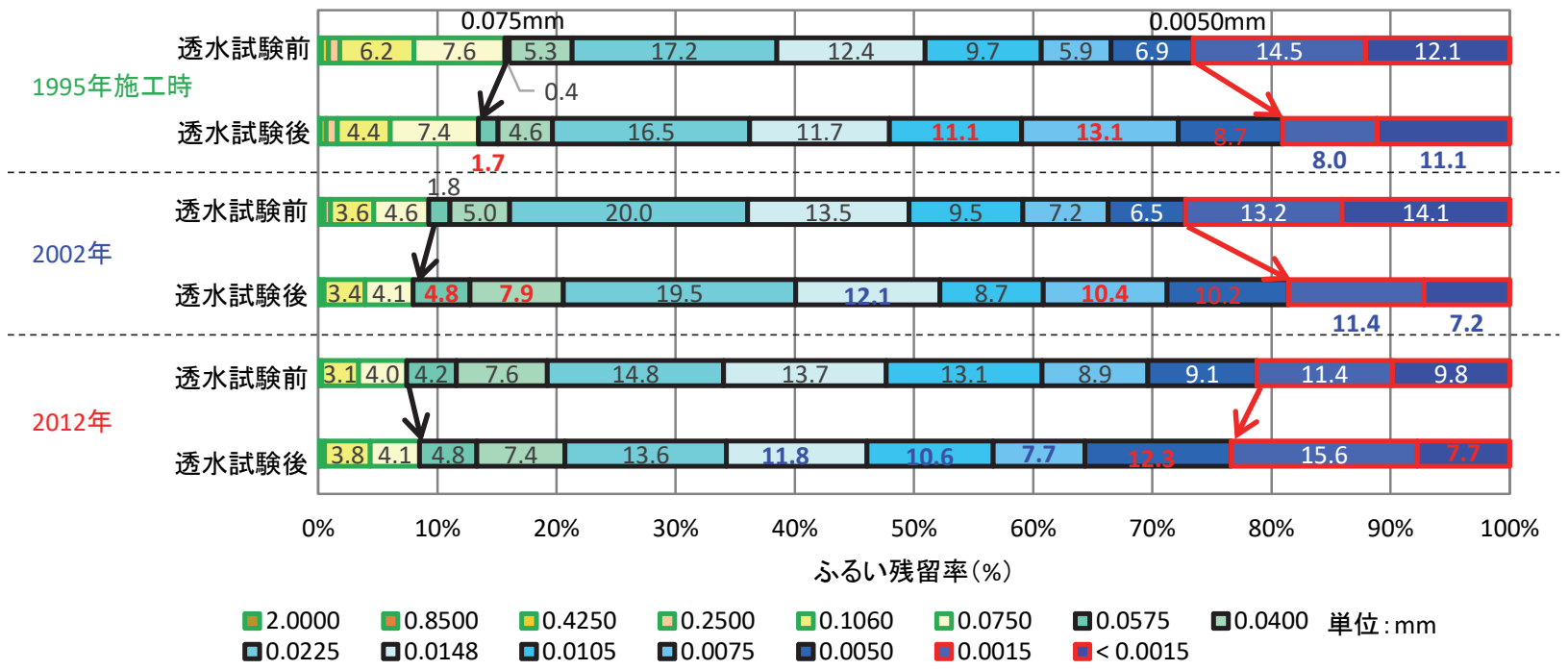

図-23 室内透水試験前後における各粒度の含有率の变化

試験を行った結果を図-22 にまとめる。また，図-23に 示すように, 1995 年 (施工時) および 2002 年の粒度で は室内透水試験前後における各粒度の残留割合をまとめ た. なお，写真-4 は室内透水試験で採取した排水の濁 り状況を撮影したものである.

各透水係数の中央值は 1995 年 (施工時) が $7.07 \times 10^{-9}$ $\mathrm{m} / \mathrm{s}, 2002$ 年が $1.05 \times 10^{8} \mathrm{~m} / \mathrm{s}, 2012$ 年が $8.42 \times 10^{-9} \mathrm{~m} / \mathrm{s}$ で, 1995 年（施工時）を基準（100\%） とすると 2002 年は 149\%，2012 年は 119\%となり，粗粒分や細粒分の割合変 化に応じて透水係数も変化してるを確認した. なお，粗 粒分の割合が高い 1995 年（施工時）は時間経過にかか わらず透水係数はほぼ一定であるが，細粒分の割合が高 い 2002 年と 2012 年は時間経過とともに透水係数が漸減

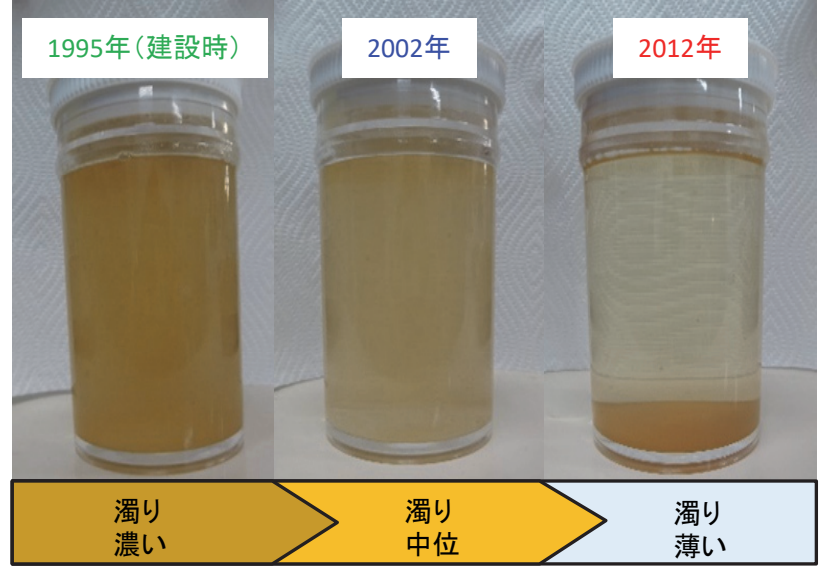

写真-4 排水の濁り具合 していく傾向にある. 
また，図-23 から室内透水試験の前後でふるい残留率 が変化しており, 試験中に細粒化が進行していることが わかる. 更に, 1995 年（施工時）と 2002 年の粒度分布 に調整した供試体では, 試験後に $5 \mu \mathrm{m}$ 未満の含有率が 低下し，2012 年の粒度分布に調整した供試体では $5 \mu \mathrm{m}$ 未満の含有率が増加しており，試験時の排水に伴う細粒 分の移動（排出）や滞積（目詰まり）が生じていると考 える. これは，前述した盛土体の物性変化の状況と定性 的に整合している．なお，写真-4 から分かるように試 験時の排水は 1995 年（施工時）が最も濁っており, 2012年で最も濁りが少ない.

これらより, 水の移動に伴い微細な土粒子は水と供に 移動・流出していることがわかり，現地における土粒子 の粒度の変化も水の移動に伴う微細な土粒子が移動した ことにより生じたものと考えられる.

\section{6. おわりに}

脆弱岩を盛土材に用いる場合，建設時には十分に締固 めを行い密実な盛土体を構築する．しかし，今回の検討 事例ではそのような盛土でおいても，経時的にスレーキ ングが進行し, 盛土内で物性の変化が生じていることが 分かった. また，スレーキングの進行に伴い微細粒化し た土粒子は，盛土内を通過する水と供に移動し，盛土の り肩付近では盛土のゆるみや空隙が発生するのに対し, 流末となる盛土のり尻付近では上方から移動した微細粒 化した土粒子により，盛土のり肩と盛土のり尻で透水性 に差が生じることが分かった（図-24）。この結果，地 下水が通過する盛土のり肩よりも排水の流末となる盛土 のり尻の透水性が低いため, 盛土内に流入寸る水量より 排出できる流量が少なくなり, 盛土内の水位が高いまま 保持される要因となったものと考えられる. また, 盛土 のり尻の自然含水比も高く飽和しやすい環境であるため, せん断抵抗力の低下も生じやすいといえる.

以上のことから，脆弱岩を用いた盛土では盛土材のス レーキング進行による物性の変化に伴い, 滑動力の増加 （水位変動の増加）や抑止力の低下（盛土のり尻の飽和 化）が生じることで，経時的に不安定化した事例を紹介 した.このことから, 盛土内の流末である盛士のり尻に 水抜きボーリングを行い排水性を向上寸ることや盛土の り尻を排水性が高い砕石等の良質材に置き換えることで, 流末の排水性の向上とせん断抵抗力を向上させることの 効果はあるものと考えられる.

謝辞 : 本報告をまとめるに当たり，現地調査結果および 動態観測結果などのデータ類を NEXCO 東日本の秋田管 理事務所より提供いただいた. 岩手大学の大河原正文准

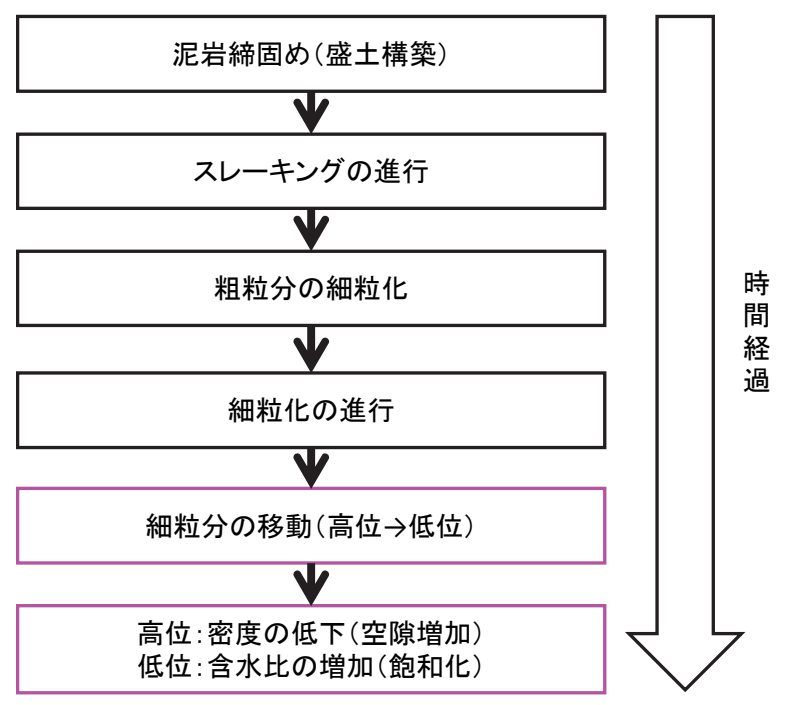

図-24脆弱岩盛土における物性の経時変化のイメージ

教授には，X線回折（XRD）と PH試験のデータ解析を して頂いただけではなく, 脆弱岩試料と盛土試料の同定 に関する有益な助言を頂けた。これをここに記し，謝意 を表します。

\section{参考文献}

1) 盛土の挙動予測と実際編集委員会 : 盛土の予測と実 際（地盤工学・実務シリーズ 2), 地盤工学会, 1996.

2) 加藤陽一, 殿垣内正人, 川井洋二: 含水比変化させ た泥岩材料の細粒化特性, 第 33 回地盤工学研究発表 会, pp. 981-982, 1998.

3）加藤陽一, 似内徹; 締固めたスレーキング特性材料 の強度低下について, 第 34 回地盤工学研究発表会, pp. 671-672, 1999.

4) 加藤陽一, 三島信雄, 緒方健治, 川井洋二 : 締固め たスレーキング材料の強度特性一スレーキングによ る強度低下の抑制について一, 第 34 回地盤工学研究 発表会, pp. 673-674, 1999.

5) 加藤陽一, 三島信雄, 緒方健治, 川井洋二 : 礫の積 比重を考慮したスレーキング性材料の品質管理, 第 54 回土木学会年次学術講演会, pp. 668-669, 1999.

6) 川井洋二, 三島信雄, 緒方健治, 加藤陽一 : スレー キング性材料を用いた高盛土の品質管理基準，第 54 回土木学会年次学術講演会, pp. 672-673, 1999.

7) 加藤陽一, 似内徹, 小林一: スレーキング性材料の 母岩の材料物性変化, 大地, 34 号, pp. 3-5, 2000.

8) 東日本高速道路: 設計要領 第一集 土工建設編, pp. 3-23, 2016.

9) 斎藤康博, 鳥本康弘 : NEXCO 中日本における防災一 の取組み, 第 20 回調査・設計・施工技術報告会, pp. 1-2, 2011.

10）日下部祐基, 伊東佳彦, 阿南修司: 岩石の乾湿繰返 しによる強度低下の定量化に関する検討, 寒地土研 研究所月報, No. 688, pp. 23-28, 2010.

11) 板橋一雄, 和田英孝, 佐藤健, 岩田賢: 7 年間暴露し た瑞浪泥岩の細粒化特性と沈下挙動, 土木学会論文 集, No. 666/III-53, pp. 269-278, 2000. 
12) 菊本統, 福田拓海・京川裕之: 破砕泥岩のスレーキ ング現象と変形挙動, 土木学会論文集 C（地圈工 学), Vol. 72, No. 2, pp. 126-135, 2016.

13）山辺晋, 黛廣志, 三島信雄, 長尾和之, 北村佳則, 加藤喜則，藤岡一頼：原位置試験から推定される高 速道路の力学特性一実態調査一, 第 39 回地盤工学研 究発表会, pp. 1311-1312, 2004.

14）中村洋丈，小林一：泥岩を用いた高速道路盛土の物 理特性と強度特性, 第 13 回岩の力学国内シンポジュ ウム講演論文集，No. 14, 2012.

15）長尾和之, 澤野幸輝, 松崎孝汰, 風間基樹, 河井正, 加村晃良：東北地方の豪雨による高速道路のり面災
害事例とその特徴について，土木学会論文集 C（地 圈工学)，Vol. 75, No. 2, pp. 198-215, 2018.

16) 東日本高速道路：設計要領 第一集 土工建設編, pp. 3-23, 2016.

17) 社団法人地盤工学会：地盤材料試験の方法と解説 （二分冊の 1）, pp. 111, 2009.

18）産総研地質調査総合センター：5 万分の 1 地質図幅 「秋田」（https://gbank.gsj.jp/geonavi/)

(Received December 18, 2019)

(Accepted July 20, 2020)

\title{
CHANGES IN PHYSICAL PROPERTIES AND CAUSES OF DEFORMATION OF EMBANKMENT USING FRAGILE ROCK SLAG AFTER START OF SERVICES
}

\author{
Koki SAWANO, Kazuyuki NAGAO, Akiyoshi KAMURA and Motoki KAZAMA
}

In the Green Tuff region at Tohoku district, many embankments have been constructed fragile rocks from taken the near site. The embankment has been constructed to tightly compact so that the air porosity is less than $15 \%$. However, in recent years, the fragile rock embankment has been deformed and collapsed due to aged deterioration, which is a problem at the site of maintaining and managing expressways. In this paper, we investigated the physical property change of the valley filling embankment in which cracks intermittently occurred on the pavement surface after several years of service start, and considered the causal relationship between changes in physical property of the embankments and their deformation. As a result, it was found that the slaking rock slag was considered to have been refined from the initial stage of the service. In addition, fine particles moved downward during the infiltration and discharge of rainwater, and loosening and hollowing occurred at the upper shoulder. In addition, it was found that the groundwater level into the embankment was raised by making the finely divided soil into a clay below the embankment, which resulted in instability of the embankment slope. In addition, the change in water permeability due to the actually adjusted particle size distribution was also evaluated. 